\title{
Research on Influencing Factors of Chinese Mobile Communication Customers' Switching Intention by Mobile Number Portability
}

\author{
Miao Miao, Jia Jia, Rui Tingting, Xiong Fangping and Li haibo \\ School of Economics and Management, Southwest Jiaotong University, Chengdu \\ 610031, China \\ miaomiao@swjtu.edu.cn
}

\begin{abstract}
In order to explore the Influencing Factors of Switching Intention by Mobile Number Portability. We build up a structural equation model for Chinese mobile customers' influence factors on MNP intention. Including competitive attraction, subjective norm, and policy perception, customer satisfaction, switching barriers, network quality, awareness rates, perceived service quality, usage habits and switching cost. According to empirical analysis, we find that customers with different perceive levels in MNP polices have significant differences in switching intention. And through the analysis and comparison, we find that the influence factors and the path coefficients of the customers' switching intention are also different when they have different perceive levels in MNP policy.
\end{abstract}

Keywords: Mobile Communication Customer, Mobile Number Portability, Switching Intention

\section{Introduction}

C Mobile number portability enables mobile communications customers to retain their mobile-phone numbers when changing from one mobile-phone Company to another. After changing their mobile phone company, customers can enjoy various mobile communications services provided by the current mobile-phone company (Chen Qiang, 2012). Number portability consists of one-way number portability and two-way number portability. On November 22 2010, number portability was first introduced to Tianjin and Hainan. At that time, number portability services were provided only by three Chinese companies and only in the above-mentioned two provinces: China Mobile, China Unicom and China Telecom. Tianjin adopted the two-way portability policy, while Hainan adopted the one-way portability policy. According to statistics from the Ministry of industry and information technology, after six months since number portability policy was introduced, only $0.403 \%$ of telecom users in Tianjin applied for number portability; the proportion was even smaller in Hainan, where only $0.073 \%$ of telecom users applied for number portability. China's number portability policy pilot areas did not display the expected effect. So far, the number portability policy is still not promoted and implemented nationwide. This paper hopes to study the factors that influence customers' inclination for receiving number portability service, construct a factor model for customers' inclination for number portability in China, so as to provide reference for policy implementation and promotion. 


\section{Present Research}

Shin et al. (2007) thinks that factors that influence the inclination include customer satisfaction and obstacles, and obstacles have greater influence on the inclination. The factor of customer satisfaction consists of expenses and service quality. The factor of obstacles consists of portability cost and customer binding. In addition, obstacles can adjust the influence of customer satisfaction on inclination. Chuang (2011) believes that customers of Taiwan mobile communications companies are much influenced by user habit when it comes to the inclination. When there is no difference in terms of customer satisfaction and portability cost, customers will continue to choose services from their current mobile-phone company instead of changing to another one. Simon et al. (2014) studied the influence of number portability policy on Mobile customers' inclination to change their mobile company. Sample data of 736 customers from 6 six global mobile communication company in Ghana were analyzed. The research suggests that factors that influence the inclination include the attitude of switching, perception of portability cost and self-efficacy. In China, Wu Pingyao (2010) believes that the main factors affecting inclination include customer satisfaction and obstacles. Zhu Ge (2011) built the Nash Bertrand price model of China's telecom operators, the study found that the number portability policy can reduce the telecom user' switching costs, then reduce the operating profit of telecom operators; at the same time can reduce the market share of dominant operator, increase the intensity of competition among telecom operators. Chen Qiang (2012) thinks that preprocess factor influence inclination by influencing portability cost. In the research model, preprocess factor include product quality, the diversity of services, the quality of services, the influence of the company, expenses, subjective norm, incentives and customer input. Portability costs mainly include the portability cost of the program, the portability cost of financial affairs and the portability cost of relations. Scholars from home and abroad built research models for the study of customers' inclination for number portability. This paper is based on the research of domestic scholar Wu Pingyao, refers to the systematic research on customers' inclination for number portability and hopes to enrich and improve the research model for the study on the factors that influence the inclination.

\section{Research Hypotheses}

\subsection{Customer Satisfaction}

Customer satisfaction is a kind of emotional reaction that is generated from the comparison of customers' perception of products and services provided by mobile communications companies and their expectation (Shin et al, 2007; Chuang, 2011). Customers of mobile communications companies can have a direct perception of products and services provided by mobile-phone companies. When customers make comparison between their perception and expectation, they will feel satisfied or dissatisfied.

Kim et al. (2004) built a customer loyalty model in their research on the mobile communications market of South Korea. The model suggests that customer loyalty is influenced by two factors, obstacles and customer satisfaction. When measuring customer satisfaction, three factors, the network quality, value-added services and customer support are taken into consideration. Empirical research shows that network quality has a significant influence on customer satisfaction. Gerpott et al. (2001) built a research model for the study of German mobile communications market that includes customer retention, customer satisfaction and customer loyalty. Network quality and awareness of charges are taken as factors that influence customer satisfaction and customer retention. The research shows that network quality and awareness of charges have a significant influence on customer 
satisfaction. Shin et al. (2007) suggests in the research of the influence of number portability policy on the mobile communications market of the US that awareness of charges has a significant positive influence on customer satisfaction. Taylor (1992) believes that the awareness of service quality will influence the degree of customer satisfaction in the research of customers' psychological path in repeated purchase. Kassim et al. (2002) points out in the research of Malaysian Communications market that customer's awareness of service quality of mobile communications business hall, for example, the reliability, responsiveness, and tangibility of customer service etc. will influence customer satisfaction. In the research of customer satisfaction on the inclination in Mobile communications, Shin et al. (2007) and Chuang (2011) both agree that customer satisfaction have a significant negative effect on inclination. Based on the above analysis, this paper proposes the following hypotheses regarding customer satisfaction.

H1: Network quality has a significant positive influence on customer satisfaction.

$\mathrm{H} 2$ : Awareness of charges has a significant positive influence on customer satisfaction.

H3: Awareness of service quality has a significant positive influence on customer satisfaction.

H4: Customer satisfaction has a significant negative influence on customers' inclination for number portability.

\section{2. Competition Attraction}

Competition attraction refers to the degree customers are attracted to other mobile-phone companies. When customers are not satisfied with the services provided by the current mobile-phone company, they will think highly of changing a communications company. When customers are satisfied with the services provided by the current mobile-phone company, they will not see much benefit from changing a communications company, and they will choose services provided by the current mobile-phone company. Wu Pingyao (2010) believes that competition attraction has significant negative influence on the inclination through obstacles. Chuang (2011) found that competitor attraction has significant positive influence on customers' inclination in the research of incentive factors and obstructive factors of the inclination in Taiwan communications market. Reichheld (1992) thinks that customer satisfaction has influence on customers' betrayal of their current mobile company. Relatively higher customer satisfaction can decrease customers' betrayal. Based on the above analysis, this paper proposes the following hypotheses regarding competition attraction.

H5: customer satisfaction has a significant negative influence on competitor attraction.

H6: competitor attraction has a significant positive influence on inclination.

\section{3 Subjective Norm}

Ajzen (1989) put forward the theory of planned behavior (TPB), which takes subjective norm as the main factor that influences behavior inclination. Subjective norm refers to the pressure coming from society when an individual makes the decision of whether to take a certain action. The higher subjective norm is, the more willing one is to take an action. In mobile communications, if the pressure of an individual or an organization is higher when deciding whether to change a mobilephone company, namely, the subjective norm is higher, the stronger the customer's inclination will be. In addition, $\mathrm{Ni}$ Weiqing believes that subjective norm can influence customers' judgment and choice of brand. When choosing an alternative brand, subjective norm will have negative influence on customers' inclination to 
change through obstacles. Based on the above analysis, this paper proposes the following hypotheses regarding subjective norm.

$\mathrm{H} 7$ : subjective norm has a significant positive influence on inclination.

H8: subjective norm has a significant negative influence on obstacles.

\section{4 Obstacles}

Obstacles are widely applied in the research of marketing. Ranaweera et al. (2003) pointed out that the more obstacles there are for changing a company, the higher customer retention is, namely the smaller the possibility that customers change a company. Han et al. (2009) found that obstacles have significant positive influence on customer retention in the research of food and beverage service industry. The presence of many obstacles will even retain customers that are not happy or satisfied with their current service. Kim et al. (2004) from the field of mobile communications pointed out those obstacles have significant negative influence on customer retention. And when it comes to factors that influence obstacles, Shin (2007) found that portability cost influences customers' inclination through obstacles in the research of customers' inclination to change a company in the communications industry in the US. Portability cost has positive influence on obstacles. Chuang (2011) divides portability cost into three categories: the cost of financial affairs, the cost of program and the cost of relations. Research shows that the three kinds of portability cost have significant negative influence on customers' inclination to change a company. Colgate et al. (2000) found that when customers develop user habit towards a certain product or service, obstacles increase and their motivation of choosing an alternative becomes less. Jolley et al. (2006) and Lia o et al.(2006) believes that user habit is a preprocess factor that influences the inclination to change, and influences inclination through obstacles. Based on the above analysis, this paper proposes the following hypotheses regarding obstacles.

H9: portability cost has a significant positive influence on obstacles.

H10: user habit has a significant positive influence on obstacles.

H11: obstacles have a significant negative influence on inclination.

\section{5 Sensitivity of Number Portability Policy}

Sensitivity of number portability policy refers to customers' judgment and perception of whether number protabiliity policy will bring convenience and whether it is necessary to implement such a policy. Shin et al. (2007) found in the research of obstacles for changing a mobile communications company in the US that number portability polity has a certain degree of influence on both inclination and obstacles. Chinese scholar Chen Qiang (2012) studied sensitivity of number portability policy as a factor that influences the inclination in the research of customers' inclination for number portability based on portability cost. The reseach shows that sensitivity of number portability policy has significant positive influence on inclination. Based on the above analysis, this paper proposes the following hypothesis regarding sensitivity of number portability policy.

H12: sensitivity of number portability policy has a significant positive influence on inclination.

\section{Empirical Study and Data Analysis}

\subsection{Questionnaire Design and Data Description}

This paper mainly refers to the measurement questions and variables in the research of Kim et al. (2004), Wu Pingyao (2010), and Yi-Fei Chuang (2011) to design measurement questions. Questionnaires are distributed on the spot and via 
the Internet. 291 valid questionnaires were collected, including 179 from male participants and 112 from female participants. Customers of China Mobile totaled 143, accounting for 49.2\%. Customers of China Unicome totaled 97, accounting for $33.3 \%$. And those of China Telecom totaled 51, accounting for 17.5\%. 22 customers had the experience of changing a company, accounting for $7.6 \%$, while 269 did not have that experience, accounting for $92.4 \%$.

\subsection{Credibility and Validity Test}

\subsubsection{Credibility Test}

This research applies SPSS17.0 to conduct credibility test on 39 scales in the questionnaire. Results are shown in Table 1, which show that the Cronbach's Alpha of the overall credibility is 0.831 , suggesting that the questionnaire has an overall high credibility. And the Cronbach's Alpha of various variables is all above 0.8 , suggesting that the credibility of all variables is high. The Cronbach's Alpha of scales that are deleted is all above 0.7 , and the value of those deleted is lower than that of variables, which suggests high credibility of scale and internal consistency.

Table 1. Reliability Test Results

\begin{tabular}{c|c|c|c}
\hline Variable & $\begin{array}{c}\text { Cronbach's } \\
\text { Alpha }\end{array}$ & Variable & $\begin{array}{c}\text { Cronbach's } \\
\text { Alpha }\end{array}$ \\
\hline $\begin{array}{c}\text { Network quality } \\
\text { chareness of } \\
\text { charges }\end{array}$ & 0.907 & User habit & 0.933 \\
\hline $\begin{array}{c}\text { Awareness of } \\
\text { service quality }\end{array}$ & 0.988 & Portability cost & 0.917 \\
\hline $\begin{array}{c}\text { Customer } \\
\text { satisfaction }\end{array}$ & 0.937 & Obstacles & 0.872 \\
\hline $\begin{array}{c}\text { Competition } \\
\text { attraction }\end{array}$ & 0.926 & Subjective norm & 0.974 \\
\hline $\begin{array}{c}\text { Sensitivity of } \\
\text { number } \\
\text { portability } \\
\text { policy }\end{array}$ & 0.951 & & - \\
\hline
\end{tabular}

\subsubsection{Validity Test}

The result of exploratory factor analysis is shown in Table 2. the MSA value of scale questions ranges from 0.870 to 0.981 . The KMO value is 0.945 . The significance level of Bartlett sphericity test is 0.000 , which shows that the MSA, $\mathrm{KMO}$ and the significance level of Bartlett sphericity test all meet the requirements. Scale questions are all suited to factor analysis. It is found after factor extraction using the principle component analysis that the factor loading value of scale questions ranges from 0.519 to 0.847 , above 0.5 . They explained $73.024 \%$ of the total variance. The above data show that the scale data constructed are valid.

Table 2. Validity Test Results

\begin{tabular}{c|c|c|c|c|c|c|c|c}
\hline SCALE & NQ1 & NQ2 & NQ3 & CP1 & CP2 & CP3 & CP4 & CS1 \\
\hline $\begin{array}{c}\text { Factor } \\
\text { loading }\end{array}$ & 0.660 & 0.687 & 0.712 & 0.764 & 0.787 & 0.698 & 0.691 & 0.680 \\
\hline Scale & CS2 & CS3 & CS4 & SP1 & SP2 & SP3 & SP4 & SP5 \\
\hline Factor & 0.678 & 0.706 & 0.679 & 0.678 & 0.677 & 0.734 & 0.794 & 0.821 \\
\hline
\end{tabular}




\begin{tabular}{c|c|c|c|c|c|c|c|c}
\hline loading & & & & & & & & \\
\hline Scale & SP6 & SC1 & SC2 & SC3 & SC4 & SC5 & SN1 & SN2 \\
\hline $\begin{array}{c}\text { Factor } \\
\text { loading }\end{array}$ & 0.771 & 0.801 & 0.803 & 0.737 & 0.822 & 0.842 & 0.635 & 0.631 \\
\hline Scale & UH1 & UH2 & UH3 & SB1 & SB2 & SB3 & PP1 & PP2 \\
\hline $\begin{array}{c}\text { Factor } \\
\text { loading }\end{array}$ & 0.811 & 0.816 & 0.824 & 0.752 & 0.754 & 0.696 & 0.847 & 0.840 \\
\hline Scale & AA1 & AA2 & AA3 & AA4 & SI1 & SI2 & SI3 & - \\
\hline $\begin{array}{c}\text { Factor } \\
\text { loading }\end{array}$ & 0.702 & 0.684 & 0.650 & 0.744 & 0.691 & 0.684 & 0.519 & - \\
\hline
\end{tabular}

\subsection{Structural Equation Model}

\subsubsection{Model Fitting}

Through calculation done by AMOS17.0, the value of model fitting is acquired. Through the comparison of the values of model fitting in Table 3 and the evaluation standard of model fitting, it is observed that the values are all up to the standard, which suggests that the hypothetical path of the model matches data from the questionnaires, and that the overall degree of fitting of the model passes the test.

Table 3. Model Fitting Standards and the Fitting Parameter Values of the Proposed Model

\begin{tabular}{|c|c|c|c|c|c|c|}
\hline \multirow{2}{*}{\multicolumn{2}{|c|}{$\begin{array}{l}\text { Indicator } \\
\text { Evaluation } \\
\text { indicator }\end{array}$}} & \multicolumn{5}{|c|}{ absolute fitting degree } \\
\hline & & & /df & & GFI & RMSEA \\
\hline \multicolumn{2}{|c|}{$\begin{array}{l}\text { Evaluation } \\
\text { standards }\end{array}$} & \multicolumn{2}{|c|}{$<3$ acceptable } & \multicolumn{2}{|c|}{$\begin{array}{c}>0.7 \text { accept } \\
>0.9 \text { comparatively } \\
\text { good }\end{array}$} & $\begin{array}{c}<0.1 \text { accept } \\
<0.05 \text { comparatively } \\
\text { good }\end{array}$ \\
\hline \multicolumn{2}{|c|}{$\begin{array}{c}\text { The proposed } \\
\text { model }\end{array}$} & \multicolumn{2}{|c|}{1.679} & \multicolumn{2}{|r|}{0.836} & 0.048 \\
\hline \multicolumn{2}{|c|}{$\begin{array}{c}\text { Evaluation } \\
\text { standards and } \\
\text { reference }\end{array}$} & \multicolumn{2}{|c|}{$\begin{array}{l}\text { Wu Minglong } \\
\text { (2010) }\end{array}$} & \multicolumn{2}{|c|}{ Armstrong (1977) } & $\begin{array}{l}\text { Wu Minglong } \\
\text { (2010) }\end{array}$ \\
\hline Indicator & \multicolumn{4}{|c|}{ Parsimony fitting degree } & \multicolumn{2}{|c|}{ Value-added fitting degree } \\
\hline $\begin{array}{c}\text { Evaluation } \\
\text { indicator } \\
\end{array}$ & \multicolumn{2}{|c|}{ PNFI } & \multicolumn{2}{|c|}{ PGFI } & CFI & NFI \\
\hline $\begin{array}{l}\text { Evaluation } \\
\text { standards }\end{array}$ & \multicolumn{2}{|c|}{$>0.5$ accept } & \multicolumn{2}{|c|}{$>0.5$ accept } & $\begin{array}{c}>0.7 \text { accept } \\
>0.9 \text { comparatively } \\
\text { good }\end{array}$ & $\begin{array}{c}>0.7 \text { accept } \\
>0.9 \text { comparatively } \\
\text { good }\end{array}$ \\
\hline $\begin{array}{c}\text { The } \\
\text { proposed } \\
\text { model }\end{array}$ & \multicolumn{2}{|c|}{0.817} & \multicolumn{2}{|c|}{0.713} & 0.962 & 0.911 \\
\hline $\begin{array}{l}\text { Evaluation } \\
\text { standards } \\
\text { and } \\
\text { reference }\end{array}$ & \multicolumn{2}{|c|}{$\begin{array}{c}\text { Wu } \\
\text { Minglong } \\
(2010)\end{array}$} & \multicolumn{2}{|c|}{$\begin{array}{l}\text { Wu Minglong } \\
\text { (2010) }\end{array}$} & Bentler (1992) & Bentler (1992) \\
\hline
\end{tabular}




\subsubsection{Path Coefficient}

The results of standardized path coefficient of factors that influence customers' inclination for number portability that is acquired through calculation done by AMOS 17.0 on data from questionnaires are shown in Table 4. The results show that in the structural equation model for the factors that influence customers' inclination for number portability, the C.R. value of various hypothetical paths is all above 1.96. And the $\mathrm{P}$ value is below 0.05 . It shows that the path hypotheses of variables in the structural equation model can pass the significance test.

Table 4. Standardized Path Coefficients

\begin{tabular}{c|c|c|c}
\hline The relationship between variables & Estimate & S.E. & C.R. \\
\hline Customer satisfaction<----network quality & $0.421^{* * *}$ & 0.048 & 7.444 \\
\hline $\begin{array}{c}\text { Customer satisfaction<----awareness of service } \\
\text { quality }\end{array}$ & $0.256^{* * *}$ & 0.058 & 4.781 \\
\hline Customer satisfaction<----awareness of charges & $0.348^{* * *}$ & 0.071 & 5.150 \\
\hline Competition attraction<----customer satisfaction & $-0.684^{* * *}$ & 0.053 & -12.956 \\
\hline Obstacles<----Subjective norm & $-0.251^{* * *}$ & 0.031 & -6.649 \\
\hline Obstacles<----Portability cost & $0.456^{* * *}$ & 0.073 & 6.371 \\
\hline Obstacles<----User habit & $0.373^{* * *}$ & 0.064 & 5.447 \\
\hline Inclination<----Competition attraction & $0.140^{* * *}$ & 0.041 & 3.089 \\
\hline Inclination<----customer satisfaction & $-0.194 * * *$ & 0.045 & -3.927 \\
\hline Inclination<----sensitivity of number portability & $0.441^{* * *}$ & 0.030 & 10.424 \\
\hline policy & $-0.269^{* * *}$ & 0.040 & -5.718 \\
\hline Inclination<----obstacles & $0.180^{* * * *}$ & 0.033 & 3.766 \\
\hline Inclination<----subjective norm & & &
\end{tabular}

(Note: $* * *$ means $\mathrm{P}<0.01)$

\subsection{Inclination for Number Portability of Customers with Different Understandings of Number Portability Policy}

\subsubsection{Analysis of Variance}

The average value of the total scale points of sensitivity of number portability policy is 6.25 . This research regards samples with PP1+PP $2 \leq 7$ as customers with low sensitivity of number portability policy, and samples with PP1+PP2 $>7$ as customers with high sensitivity of number portability policy. According to the result of Table 5, Analysis of variance, $\mathrm{F}=148.970$. The significance level $\mathrm{P}=0.000<0.05$, up to the significance level, which shows there is a significant difference in terms of inclination for portability between customers with high sensitivity of number portability policy and customers with low sensitivity of number portability policy number portability . 
Table 5. Variance Analysis of Customers with High Sensitivity of
Number Portability Policy and Customers with Low Sensitivity of
Number Portability Policy Inclination

\begin{tabular}{c|c|c|c|c|c|c|c}
\hline \multirow{2}{*}{$\begin{array}{c}\text { Snsitivity } \\
\text { of policy }\end{array}$} & \multicolumn{4}{|c|}{ Descriptive Statistics } & \multicolumn{2}{c}{ Variance Test } \\
\cline { 2 - 6 } & mean & $\begin{array}{c}\text { standard } \\
\text { deviation }\end{array}$ & $\begin{array}{c}\text { standard } \\
\text { error }\end{array}$ & \multicolumn{2}{|c|}{$\begin{array}{c}95 \% \text { confidence } \\
\text { interval }\end{array}$} & \multirow{2}{*}{ F } & significance \\
\cline { 5 - 6 } & & & & minimum & maximum & & \\
\hline Low & 7.2468 & 1.99775 & 0.16098 & 6.9287 & 7.5648 & 148.970 & 0.000 \\
\hline High & 10.1971 & 2.12423 & 0.18149 & 9.8382 & 10.5560 & & \\
\hline
\end{tabular}

4.4.2. Comparative Analysis of Factors That Influence the Inclination for Number Portability of Customers with Different Degrees of Sensitivities of the Policy

Statistics from Table 6 show that the values of model fitting of inclination for number portability of customers with either high or low sensitivity are up to the standard, and that the hypothetical path of the model matches data from the questionnaires. The overall degree of fitting passes the test.

Table 6. Fitting Test Results

\begin{tabular}{c|c|c|c|c|c|c|c}
\hline $\begin{array}{c}\text { Evaluation } \\
\text { indicator }\end{array}$ & $\chi^{2} / \mathrm{df}$ & GFI & RMSEA & PNFI & PGFI & CFI & NFI \\
\hline $\begin{array}{c}\text { High } \\
\text { sensitivity }\end{array}$ & 1.784 & 0.711 & 0.076 & 0.731 & 0.608 & 0.906 & 0.810 \\
\hline $\begin{array}{c}\text { Low } \\
\text { sensitivity }\end{array}$ & 1.693 & 0.723 & 0.067 & 0.722 & 0.620 & 0.906 & 0.800 \\
\hline
\end{tabular}

Results of comparative analysis of inclination for portability of customers with different sensitivities of the policy are shown in Table 7. Assuming C.R.> 1.96, $\mathrm{P}<0.05$ are the test standard, the hypothesis that customer satisfaction of customers with high sensitivity of number portability policy has influence on inclination cannot pass the test, and the hypotheses that competition attraction and subjective norm of customers with low sensitivity of number portability policy have influence on inclination fail to pass the test. In addition, there are remarkable differences between the inter-influences of factors that influence the inclination of customers with high sensitivity and those with low sensitivity.

Table 7. Structural Equation Model for Inclination for Number Portability of Customers with Different Sensitivities of the Policy

\begin{tabular}{c|c|c|c|c|c|c}
\hline \multirow{2}{*}{$\begin{array}{c}\text { The relationship } \\
\text { between variables }\end{array}$} & \multicolumn{2}{|c|}{ High sensitivity of policy } & \multicolumn{3}{|c}{ Low sensitivity of policy } \\
\cline { 2 - 7 } & Estimate & S.E. & C.R. & Estimate & S.E. & C.R. \\
\hline $\begin{array}{c}\text { Customer } \\
\text { satisfaction<---- } \\
\text { network quality }\end{array}$ & $0.371 * * *$ & 0.063 & 4.425 & $0.434 * * *$ & 0.058 & 6.718 \\
\hline $\begin{array}{c}\text { Customer } \\
\text { satisfaction<---- } \\
\text { awareness of charges }\end{array}$ & $0.395 * * *$ & 0.097 & 4.271 & $0.316^{* * *}$ & 0.037 & 5.740 \\
\hline $\begin{array}{c}\text { Customer } \\
\text { satisfaction<---- } \\
\text { awareness of service }\end{array}$ & $0.247 * * *$ & 0.071 & 3.312 & $0.373^{* * *}$ & 0.070 & 5.653 \\
\hline
\end{tabular}




\begin{tabular}{|c|c|c|c|c|c|c|}
\hline quality & & & & & & \\
\hline $\begin{array}{c}\text { Competition } \\
\text { attraction<---- } \\
\text { customer satisfaction }\end{array}$ & $\begin{array}{c}- \\
0.698 * * *\end{array}$ & 0.070 & -9.145 & $-0.606 * * *$ & 0.092 & $\begin{array}{c}- \\
7.512\end{array}$ \\
\hline $\begin{array}{l}\text { Obstacles<---- } \\
\text { subjective norm }\end{array}$ & $\begin{array}{c}- \\
0.182 * * *\end{array}$ & 0.055 & -3.380 & $-0.269 * * *$ & 0.041 & $\begin{array}{c}- \\
4.674\end{array}$ \\
\hline $\begin{array}{c}\text { Obstacles<----user } \\
\text { habit }\end{array}$ & $0.437 * * *$ & 0.088 & 4.405 & $0.348 * * *$ & 0.093 & 3.866 \\
\hline $\begin{array}{l}\text { Obstacles<---- } \\
\text { portability cost }\end{array}$ & $0.430 * * *$ & 0.094 & 4.252 & $0.516^{* * *}$ & 0.120 & 5.188 \\
\hline $\begin{array}{c}\text { Inclination<---- } \\
\text { customer satisfaction }\end{array}$ & -0.173 & 0.059 & -1.919 & $-0.290 * * *$ & 0.064 & $\begin{array}{c}- \\
3.664\end{array}$ \\
\hline $\begin{array}{c}\text { Inclination<---- } \\
\text { competition attraction }\end{array}$ & $0.289 * * *$ & 0.063 & 3.279 & 0.086 & 0.048 & 1.269 \\
\hline $\begin{array}{c}\text { Inclination<-- } \\
\text { sensitivity of number } \\
\text { portability policy }\end{array}$ & $0.261 * * *$ & 0.124 & 3.380 & $0.401 * * *$ & 0.050 & 5.542 \\
\hline $\begin{array}{l}\text { Inclination<---- } \\
\text { subjective norm }\end{array}$ & $0.345 * * *$ & 0.046 & 4.397 & 0.060 & 0.040 & 0.816 \\
\hline $\begin{array}{c}\text { Inclination<---- } \\
\text { obstacles }\end{array}$ & $\begin{array}{c}- \\
0.270 * * *\end{array}$ & 0.046 & -3.378 & $-0.326 * * *$ & 0.061 & $\begin{array}{c}- \\
4.053 \\
\end{array}$ \\
\hline
\end{tabular}

\section{Conclusion}

(1) Competition attraction, subjective norm and sensitivity of number portability policy have positive influence on customers' inclination for number portability. Mobile-phone Company can increase the number of customers from Competitor Company who change their current company through improving the degree of competition attraction, the influence of subjective norm and that of the sensitivity of number portability policy.

(2)Customer satisfaction and obstacles have negative influence on inclination. Mobile-phone companies can decrease the number of customers who change to other company through improving customer satisfaction and increasing obstacles. In addition, customer satisfaction has significant negative influence on competition attraction. Improving customer satisfaction can reduce competition attraction to the current customers of a company, and thus can reduce the number of customers who change their mobile company. However, obstacles are negatively influenced by subjective norm. Mobile-phone companies need to be concerned with the influence of subjective norm on their current customers. They can improve the effect of subjective norm and decrease obstacles to increase the inclination to change a mobile company of customers from competitor companies.

(3) Mobile-phone companies should focus on improving network quality, awareness of charges, and awareness of service quality, so as to raise the satisfaction of registered customers and lower the possibility that their customers switch to other communications companies;

(4) Mobile-phone company should pay attention to developing customers' user habit to increase users' loyalty, and to increasing users' portability cost to increase obstacles for changing a mobile company and thus reduce the possibility that current users switch to another company.

(5) When the number portability policy is implemented, mobile-phone companies should make different marketing plans based on customers' different sensitivities of number portability policy to increase the inclination to switch a company of 
customers from competitor companies and reduce the possibility that their own customers change to another company.

\section{Acknowledgement}

This project is supported by Mobile payment operators in the tourism market, the impact of the Game (LY10-27); Sichuan Provincial Education Department from 2010-2012; Reconstruction of the mobile Internet era of tourism industry value chain (10XJC79000) education of Humanities and Social Science Fund 2010; Based on the level Research on the mobile payment industry model analysis method (SWJTU12CX119); Central Science and Technology Innovation Fund for 2012.

\section{References}

[1] I. Ajzen, "Attitudes, personality, and behavior [M]", McGraw-Hill International, (2005).

[2] J. S. Armstrong and T. S. Overton, "Estimating nonresponse bias in mail surveys [J]", Journal of Marketing Research (JMR), vol. 14, no. 3, (1977), pp. 396-402.

[3] P. M. Bentler, "On the fit of models to covariances and methodology to the $<$ em $>$ Bulletin, $</$ em $>$ [J]", Psychological bulletin, vol. 112, no. 3, (1992), p. 400.

[4] C. Qiang, "Study on Customer Inclination of Number Portability based on Costs [D]", Chongqing University of Post and Telecommunications, (2012).

[5] Y. F. Chuang, "Pull-and-suck effects in Taiwan mobile phone subscribers switching intentions [J]", Telecommunications Policy, vol. 35, no. 2, (2011), pp. 128-140.

[6] M. R. Colgate and P. J. Danaher, "Implementing a customer relationship strategy: the asymmetric impact of poor versus excellent execution [J]", Journal of the Academy of Marketing Science, vol. 28, no 3, (2000), pp. 375-387.

[7] T. J. Gerpott, W. Rams and A. Schindler, "Customer retention, loyalty, and satisfaction in the German mobile cellular telecommunications market [J]", Telecommunications policy, vol. 25, no. 4, (2001), pp. 249-269.

[8] H. Han, K. J. Back and B. Barrett, "Influencing factors on restaurant customers' revisit intention: The roles of emotions and switching barriers [J]", International Journal of Hospitality Management, vol. 28, no. 4, (2009), pp. 563-572.

[9] B. Jolley, R. Mizerski and D. Olaru, "How habit and satisfaction affects player retention for online gambling [J]", Journal of Business Research, vol. 59, no. 6, (2006), pp. 770-777.

[10] N. M. Kassim and J. Bojei, "Service quality: gaps in the Malaysian telemarketing industry [J]", Journal of Business Research, vol. 55, no. 10, (2002), pp. 845-852.

[11] M. K. Kim, M. C. Park and D. H. Jeong, "The effects of customer satisfaction and switching barrier on customer loyalty in Korean mobile telecommunication services [J]", Telecommunications policy, vo. 28, no. 2, (2004), pp. 145-159.

[12] C. Liao, P. Palvia, H. N. Lin, "The roles of habit and web site quality in e-commerce [J]", International Journal of Information Management, vol. 26, no. 6, (2006), pp. 469-483.

[13] W. Ni, "Study on Customer Inclination of Switching Brands [D]", Yangzhou University, (2010).

[14] C. Ranaweera and J. Prabhu, "The influence of satisfaction, trust and switching barriers on customer retention in a continuous purchasing setting [J]", International journal of service industry management, vol. 14, no. 4, (2003), pp. 374-395.

[15] F. F. Reichheld, "Loyalty-based management [J]", Harvard business review, vol. 71, no. 2, (1992), pp. 64-73.

[16] D. H. Shin, "A study of mobile number portability effects in the United States [J]", Telematics and Informatics, vol. 24, no. 1, (2007), pp. 1-14.

[17] D. H. Shin and W.F. Kim, "Forecasting customer switching intention in mobile service: An exploratory study of predictive factors in mobile number portability [J]", Technological Forecasting and Social Change, vol. 75, no. 6, (2007), pp. 854-874.

[18] G. N. Simon, A. N. Benjamin and F. M. Anthony, "Effect of Mobile Number Portability Adoption on Consumer Switching Intention [J]”, International Journal of Marketing Studies, vol. 6, no. 2, (2014), pp. $117-134$

[19] J. W. Taylor, "The role of risk in consumer behavior [J]", The Journal of Marketing, (1974), pp. 54-60.

[20] M. Wu, "SPSS Operation and Application: Questionnaire Statistical Analysis Practice[J], (2010).

[21] P. Wu, "Study on the Influence of One-way Number Portability Policy on Customer Inclination toward Number Portability [D]", Chongqing University of Post and Telecommunications, (2010).

[22] G. Zhu, J. Dai and Y. Lv, "The influence of market structure change by Number portability of mobile communications [J]", Journal of communication university of China: Journal of Natural Sciences, vol. 18 , no. 1, (2011), pp. 36-44. 